\title{
Variation of whole body amino acid profile in Eurasian perch Perca fluviatilis L. reared in an inorganic fertilized pond
}

\author{
E. D. FIOGBE
}

Unité de Recherche sur les Zones Humides, Département de Zoologie et Génétique, Faculté des Sciences et Techniques, Université d'Abomey-Calavi, BP 526 Cotonou, Bénin. E-mail: edfiogbe@yahoo.fr, fiogbe@syfed.bj.refer.org

\begin{abstract}
Ten thousand eggs of Eurasian perch ready to hatch were stocked in a cage in a pond where zooplankton population was abundant. The pond was fertilized at the beginning and every week until day 85 , with superphosphate and ammonium sulphate to obtain $30 \mu \mathrm{g} \mathrm{l}^{-1}$ for phosphorus and $600 \mu \mathrm{g} \mathrm{l}^{-1}$ of nitrogen. This fertilization is known to maintain abundant zooplankton for fish growth, without low dissolved oxygen, high ammonia and $\mathrm{pH}$ occurring regularly in fertilized pond, due to blue-green phytoplankton bloom. Water quality was monitored through measurement of temperature, dissolved oxygen, $\mathrm{pH}$, nitrogen, phosphorous and chlorophyll a. Samples of fish were analyzed on the Water Pico-Tag amino acid analysis system. For the study period, survival rate calculated after counting all survival fish reached $7.5 \%$. Final fish body weight averaged $0.850 \pm 0.678 \mathrm{~g}$ (measured for $600 \mathrm{fish}$ ), but some large fish reached up to $2.1 \mathrm{~g}$. During the first week, specific growth rate of fish was very high $\left(\mathrm{SGR}=38 \% \mathrm{day}^{-1}\right)$, and then decreased to $8.5 \% \mathrm{day}^{-1}$ at harvesting. Average SGR for the whole period was $9.3 \% \mathrm{day}^{-1}$. Except glycine, alanine proline and aspartine, whole body amino acid composition remained stable throughout the growing period.

(C) 2009 International Formulae Group. All rights reserved.
\end{abstract}

Keywords: Water quality, zooplankton, fish growth, protein quality.

\section{INTRODUCTION}

Since the quantitative amino acid requirements have only been established for a limited number of fish, certain investigators have used various methods to estimate the amino acid needs of other fish in order to design and improve their test diets. Wilson and Poe (1985) have reported that the amino acid patterns of fish eggs and whole body tissue have been used for this purpose in channel catfish Ictalurus punctatus. Rumsey and Ketola (1975) reported that improved growth was observed when Atlantic salmon fry were fed casein diets supplemented with essential amino acids to simulate levels in isolated fish protein. Similar improvements were observed when rainbow trout fingerlings were fed soybean diets supplemented with essential amino acids to simulate those in either trout eggs or isolated fish protein. In the same way, other recent reports in fish nutrition studies have helped reveal some of the complex relationships between nutrient income and body store. Most experiments conducted in fish have shown that total essential amino acid (EAA) incrementation in whole body included cystine and tyrosine account for about $34 \%$ of total digestible protein ingested (Ravi and Devaraj, 1991; Arai and Ogata, 1993; Borlongan and Colosso, 1993; Ng and Hung, 1995). On the other hand, when cultivated under optimal conditions or when fed well-balanced dietary amino acids, the body amino acid profile of fish did not change during the development of catfish from 30 to $863 \mathrm{~g}$ (Wilson and Poe, 
1985); of common carp from 200 to $1000 \mathrm{~g}$ (Schwarz and Kirchgessner, 1988) and of white sturgeon from 20 to $535 \mathrm{~g}$ ( $\mathrm{Ng}$ and Hung, 1995).

Considering these statements, and the fact that when fish is fed in its natural environment, the deficiency of some amino acids in a given live prey can be counterbalanced by the excess of the same amino acids in other live organisms (Fiogbe, 1996), Eurasian perch Perca fluviatilis, a new candidate for intensive aquaculture in temperate regions were cultivated from larval to juvenile stages in a pond containing abundant quantity of zooplankton and macroinvertebrates. Profiles of amino acids were determined throughout their growth to check which body composition can be obtained when fertilizing a pond with an adequate N:P ratio $(20: 1)$ as reported by Qin and Culver (1992) in yellow perch.

\section{MATERIALS AND METHODS Fish and facilities}

To avoid the high mortality of perch larvae which occurs after manipulation, eyed stage eggs of Eurasian perch, previously incubated in the laboratory, have been introduced into the pond. About 10000 eggs (129 g of $\left.12.9 \mathrm{mg} \cdot \mathrm{egg}^{-1}\right)$ ready to hatch were stocked in a wood cage $(40 \mathrm{~cm} \times 40 \mathrm{~cm} \times 50$ $\mathrm{cm})$ recovered by net to facilitate the self liberation of larva after their hatching. The cage was introduced in a pond (earthern, $0.011 \mathrm{ha}, 80 \mathrm{~cm}$ depth supplied with a stream water) 10 days after the first fertilization, where zooplankton population, mainly rotifers, cladocerans, and few copepods were growing. The pond was fertilized at the beginning with $20 \mathrm{~g}$ superphosphate and $1 \mathrm{~kg}$ ammonium sulphate to obtain concentrations of $30 \mu \mathrm{g} \mathrm{l}^{-1}$ for phosphorus and $600 \mu \mathrm{g} \mathrm{l}^{-1}$ of nitrogen. These concentrations of phosphorus and nitrogen were adjusted every week after their analysis in the pond water. This adequate fertilization with high $\mathrm{N}: \mathrm{P}$ ratio $(20: 1)$ is known to maintain in pond abundant zooplankton for fish growth, without the problems of low dissolved oxygen, and high ammonia and $\mathrm{pH}$ occurring regularly in fertilized systems with low N:P $(<7: 1)$, due to development of blue-green phytoplankton bloom with little or none of eligible algae for zooplankton (Qin and Culver, 1992; Culver,
1996). According to our planning because we are alone, water quality based in situ measurements of temperature, $\mathrm{pH}$, and primary production (chlorophyll a) were monitored every three days from the day 1 of first fertilization except dissolved oxygen which measurement was dependent upon the availability of oxymeter in the laboratory. Other parameters such as N, P and zooplankton concentration were monitored weekly from the day 17 where the cage was putted in the pond. Temperature, dissolved oxygen and $\mathrm{pH}$ were measured at $10.00 \mathrm{am}$ (oxy-thermometer Ysi model 58 and $\mathrm{pH}$ thermometer WTW E56), while $\mathrm{N}-\mathrm{NH}_{4}{ }^{+}$and $\mathrm{P}_{-} \mathrm{PO}_{4}{ }^{3-}$ ions and chlorophyll a concentrations were assayed by spectrophotometry. $\mathrm{N}^{-\mathrm{NH}_{4}}{ }^{+}$ was analyzed with the method of dichloroisocyanurate and salicylate of sodium (HMSO, 1981). P-PO4 ${ }^{3-}$ was analyzed with the method of ammonium molybdate (Golterman and Clymo, 1969). Chlorophyll a was extracted with acetone/methanol $(5: 1)$ and quantified following the method of Pechar (1987). Fertilizers were added after analysis to adjust $\mathrm{P}$ and $\mathrm{N}$ concentrations to $30 \mu \mathrm{g} \mathrm{l^{-1 }}$ and $600 \mu \mathrm{g}^{-1}$ respectively. Zooplankton (rotifers, cladocerans and copepods) were sampled by $63 \mu \mathrm{m}$ filtration of a 201 pond water sample and their concentration checked with a petri bottle under binocular. Thirty fish were sampled periodically for individual growth assessment with a micro balance Pioneer $(0.1$ $\mathrm{mg}$ standard error) and frozen at $-20{ }^{\circ} \mathrm{C}$ for biochemical analysis (amino acid contents) in order to determine the variations of these nutrients during larval and early juvenile development in the pond. Water level in pond has been adjusted two times during experiment with about $2 \mathrm{~m}^{3}$. The pond was drained 75 days after egg stocking and all survival fish have been counted and weighted.

The following formula was used to calculate specific growth rate (SGR):

$\operatorname{SGR}\left(\%\right.$ day $\left.^{-1}\right)=[(\ln$ FBW-ln IBW $)] 100 . \Delta \mathrm{t}^{-1}$

where IBW, FBW = initial and final body weight of fish $(\mathrm{mg}), \Delta \mathrm{t}=$ time interval, $\ln$ is the natural logarithm.

\section{Amino acid analysis in fish carcass}

Samples of 30 fish were dried in a vacuum pump and grounded, and $2 \times 10 \mathrm{mg}$ of the homogenized fish powder were 
weighed (down to $0.1 \mathrm{mg}$ ) for analysis. All samples for amino acids analysis were hydrolysed in duplicate with $6 \mathrm{~N} \mathrm{HCl}$ at 115 ${ }^{\circ} \mathrm{C}$ during $22 \mathrm{~h}$ and derivatized with phenylisothiocyanate (PITC) before chromatographic separation using a Pico-Tag reversed phase column $\mathrm{C} 18$ of $30 \mathrm{~cm}$ (Water, Division of Millipore). The amino acid analysis was performed on the Water PicoTag amino acid analysis system which consisted of two M510 solvent delivery systems controlled by a Water 840 System and a Water 490 multiwavelengh detector (240 $\mu \mathrm{m} / 0.2$ AUFS) following a modified procedure of Hagen et al. (1989). Samples were manually injected into the system. Chromatographic peaks were integrated, identified, and quantified with Water Expert chromatography (version 6.2) software package by comparing it to known standards (amino acid standard H, Pierce Rockford, IL).

\section{Statistical analysis of data}

All data were subjected to factorial analysis of variance using one way ANOVA (Dagnelie, 1975). Treatment effects were considered significant at $\mathrm{p}<0.05$. If interactions were significant, orthogonal contrasts were performed to detect mean separation.

\section{RESULTS}

Water quality and zooplankton availability

Temperature, $\mathrm{pH}$ and dissolved oxygen variations in the ponds are shown in Figure 1. Temperature and dissolved oxygen were varied generally between 10 and $24{ }^{\circ} \mathrm{C}$ and between 8 and $15 \mathrm{mg} .1^{-1}$ respectively during the morning hours, except in May when dissolved oxygen dropped to less than $5 \mathrm{mg} . \mathrm{l}^{-1}$ for few days, without any apparent effects on perch survival. $\mathrm{pH}$ varied between 7-10 and Chl a varied between 6.4 - $10.5 \mu \mathrm{g} . \mathrm{l}^{-1}$ (Figure $1)$. The high levels of algal production $(>10$ $\left.\mu \mathrm{g} .1^{-1}\right)$ at the end of April and May and in mid June increased nutrient consumption, and thus required more amount for fertilizers $\mathrm{P}$ and $\mathrm{N}$ adjustment to levels $30 \mu \mathrm{g}$ and $600 \mu \mathrm{g}$ respectively, between may and late June.

Rotifer and cladoceran concentrations largely varied during the perch growing period, with 3 peaks occurring in May and June in rotifer populations (up to 2575 ind. $1^{-}$) and one peak of cladocerans in May (up to 175 ind. $1^{-1}$ ) (Figure 2). Except the peak in June, cladoceran concentration remained relatively low (less than 25 ind. $1^{-1}$ ), but increased progressively in July. Copepods were very scarce throughout the study period, ranging from 0 to 17 ind. $1^{-1}$.

\section{Survival and growth of fish}

For the study period, survival rate calculated after counting all survival at the end of the experiment, reached $7.5 \%$. Final fish body weight averaged $0.850 \pm 0.678 \mathrm{~g}$ measured for 600 individual weight, but some large fish reached up to $2.1 \mathrm{~g}$. Coefficient of variation in weight increased progressively from hatching $(6.88 \%)$ until day $75(\mathrm{CV}=$ $80 \%$ ). During the experiment period, fish growth followed the exponential relationships $\left(y=a e^{b x}\right.$ Figure 3). During the first week, specific growth rate of fish was very high $\left(\mathrm{SGR}=38 \%\right.$ day $\left.^{-1}\right)$, and then decreased to $8.5 \%$ day $^{-1}$ at harvesting. Average SGR for the whole period was $9.3 \%$ day $^{-1}$.

\section{Amino acid composition}

Except glycine, alanine and proline which increased with fish size $(5.92 \%, 5.31 \%$ and $4.31 \%$ in fish of $0.99 \mathrm{mg}$ body weight to $7.97 \%, 6.56 \%$ and $4.79 \%$ in fish of $2.07 \mathrm{~g}$, respectively) and aspartine which significantly decreased from 9.97 to $7.63 \%$, whole body amino acid composition remained stable throughout the growing period in pond (Table). Lysine was the unique essential amino acid which varied significantly during the perch growth, but no significant differences $(p>0.95)$ appeared between the early larval and juvenile stages.

\section{DISCUSSION}

During this experiment, rearing conditions in pond were suitable for the growth of Eurasian perch. The temperature range $\left(10-40^{\circ} \mathrm{C}\right)$ obtained in the present study is similar to what was suggested by Guma'a (1978) and Wang and Eckmann (1994) for good survival of perch from fertilization to swim-up (6-24 $\left.{ }^{\circ} \mathrm{C}\right)$. Kestemont et al. (1996) reported an optimal temperature of $23{ }^{\circ} \mathrm{C}$ for early development of perch and reported a growth decrease for temperature higher than $25{ }^{\circ} \mathrm{C}$. Their results indicate that the 

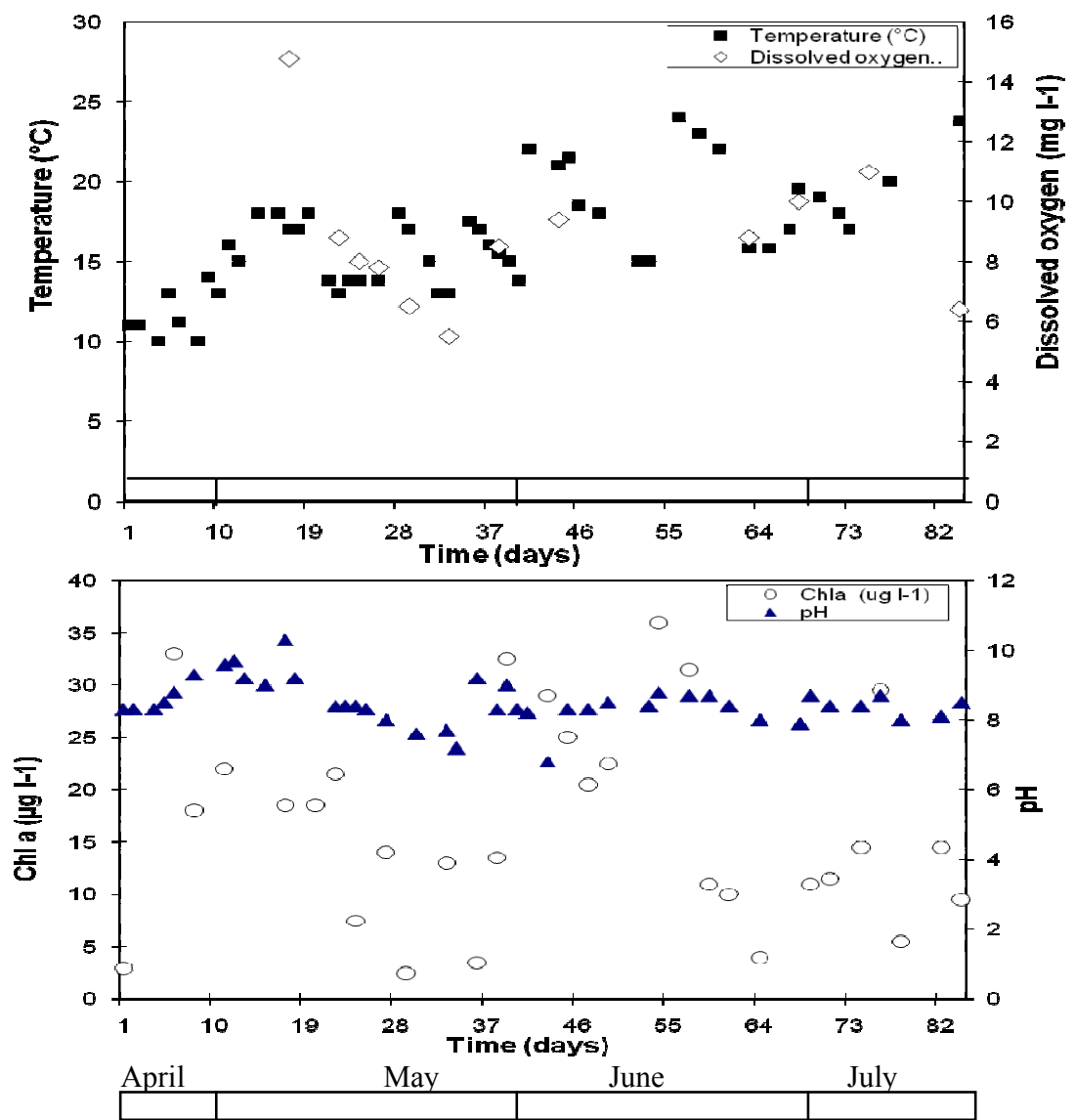

Figure 1: Temperature, dissolved oxygen, $\mathrm{pH}$ and Chlorophyll a concentration in an inorganically fertilized pond stocked with Eurasian perch larvae.

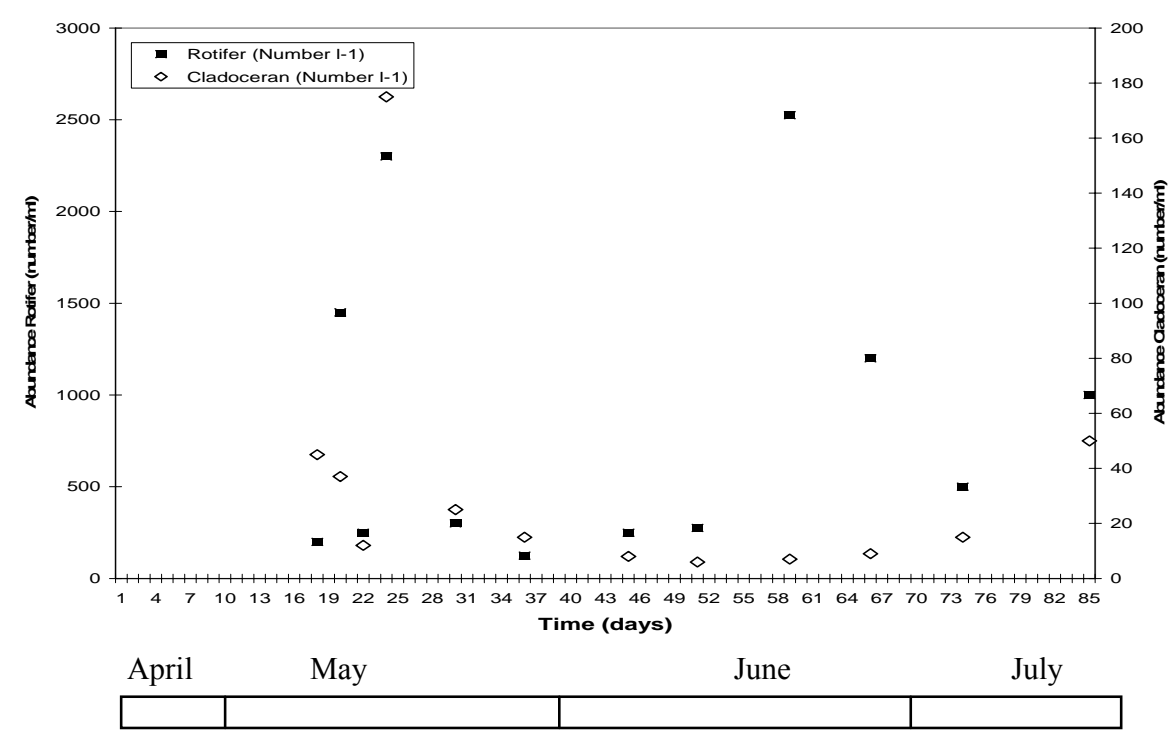

Figure 2: Abundance of major zooplankton populations (rotifers and cladocerans) in an inorganically fertilized pond stocked with Eurasian perch larvae. 


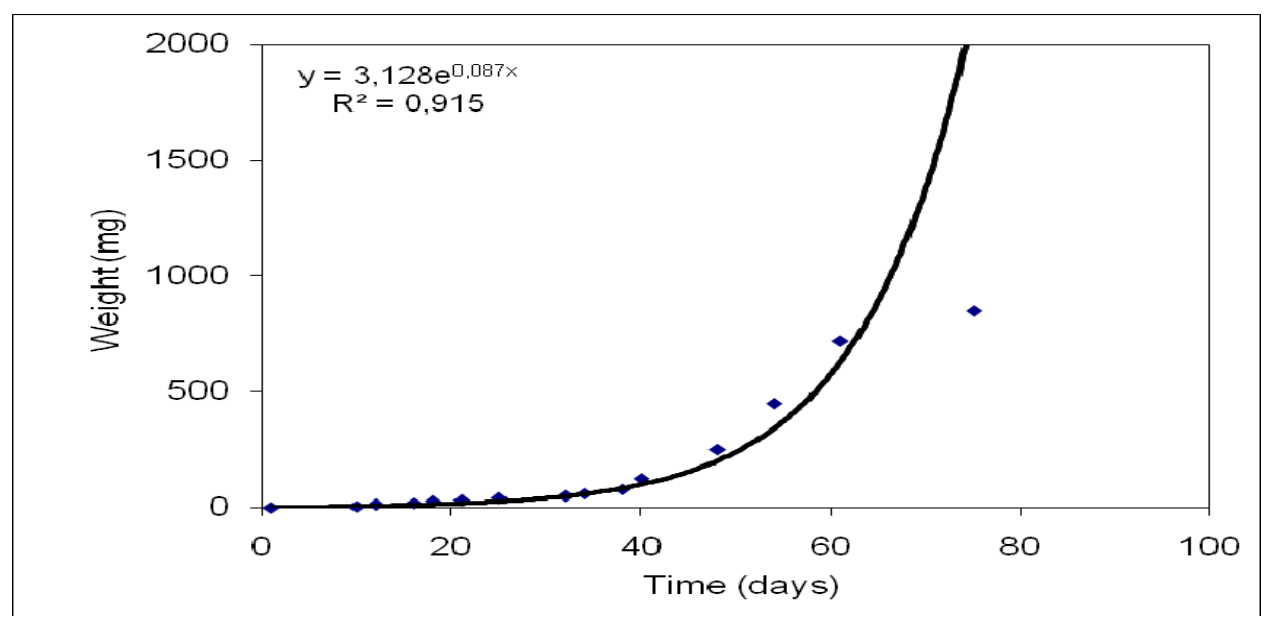

Figure 3: Growth (mean body weight) of Eurasian perch stocked in an inorganically fertilized pond from hatching until 75-day old.

Table 1: Body amino acid composition ( $\mathrm{g} / 100 \mathrm{~g}$ of total amino acids) in different stages of Eurasian perch rearing in a fertilized pond.

\begin{tabular}{llccccc}
\hline Fish body & 0.99 & 34.51 & 75.37 & 266.00 & 338.70 & 2071.00 \\
weigth & \pm 0.11 & \pm 16.08 & \pm 109.41 & \pm 202.81 & \pm 261.25 & \pm 147.02 \\
(mg) & & & & & & \\
\hline
\end{tabular}

\begin{tabular}{|c|c|c|c|c|c|c|c|c|c|c|c|c|}
\hline \multicolumn{13}{|c|}{ Amino acids (g/100g total) } \\
\hline ALA & $5.31 \mathrm{a}$ & \pm 0.06 & $5.53 \mathrm{a}$ & \pm 0.43 & $5.97 b$ & \pm 0.13 & $6.09 \mathrm{~b}$ & \pm 0.36 & $6.06 \mathrm{~b}$ & \pm 0.00 & $6.56 \mathrm{c}$ & \pm 0.06 \\
\hline ARG & $7.14 a$ & \pm 0.39 & 6.62a & \pm 0.53 & 6.49a & \pm 0.21 & 6.31a & \pm 0.31 & 6.31a & \pm 0.14 & 6.18a & \pm 0.10 \\
\hline ASP & $9.97 \mathrm{a}$ & \pm 0.71 & $9.41 \mathrm{a}$ & \pm 0.38 & $9.54 \mathrm{a}$ & \pm 0.79 & $8.03 b$ & \pm 0.49 & $8.65 b$ & \pm 0.65 & $7.63 \mathrm{c}$ & \pm 0.17 \\
\hline CYS & $0.51 \mathrm{a}$ & \pm 0.08 & $0.78 b$ & \pm 0.14 & $0.39 \mathrm{c}$ & \pm 0.12 & $0.27 \mathrm{~d}$ & \pm 0.09 & $0.42 \mathrm{c}$ & \pm 0.19 & $0.58 \mathrm{a}$ & \pm 0.02 \\
\hline GLU & $14.48 \mathrm{a}$ & \pm 1.84 & $14.52 \mathrm{a}$ & \pm 0.34 & $14.77 b$ & \pm 0.56 & $15.50 \mathrm{a}$ & \pm 0.00 & $14.56 \mathrm{a}$ & \pm 0.32 & $14.10 \mathrm{c}$ & \pm 0.11 \\
\hline GLY & $5.92 \mathrm{a}$ & \pm 0.39 & $6.27 \mathrm{a}$ & \pm 0.47 & $6.42 b$ & \pm 0.10 & $7.07 \mathrm{c}$ & \pm 0.48 & $7.07 \mathrm{c}$ & \pm 0.05 & $7.97 \mathrm{~d}$ & \pm 0.05 \\
\hline HIS & $2.86 a$ & \pm 0.46 & $3.04 a$ & \pm 0.44 & $3.29 a$ & \pm 0.79 & $3.26 a$ & \pm 0.18 & 3.10a & \pm 0.06 & $2.88 a$ & \pm 0.02 \\
\hline ILE & $5.17 a$ & \pm 0.42 & 5.07a & \pm 0.50 & $5.06 a$ & \pm 0.06 & 5.11a & \pm 0.22 & $5.02 a$ & \pm 0.14 & $5.13 a$ & \pm 0.11 \\
\hline LEU & $7.80 \mathrm{a}$ & \pm 1.04 & 7.92a & \pm 1.64 & 7.50a & \pm 1.11 & 7.83a & \pm 0.11 & $7.29 a$ & \pm 0.30 & 8.06a & \pm 0.02 \\
\hline LYS & 8.63a & \pm 0.62 & 8.49a & \pm 0.28 & 7.96ab & \pm 0.20 & 7.73b & \pm 0.17 & $8.29 a$ & \pm 0.09 & 8.83a & \pm 0.28 \\
\hline MET & $2.50 \mathrm{a}$ & \pm 0.21 & 2.83a & \pm 0.65 & 3.01a & \pm 0.27 & $2.90 \mathrm{a}$ & \pm 0.21 & $3.22 \mathrm{a}$ & \pm 0.31 & 3.11a & \pm 0.04 \\
\hline PHE & $4.35 a$ & \pm 0.44 & $4.48 a$ & \pm 0.52 & $4.52 a$ & \pm 0.01 & 4.07a & \pm 0.22 & $4.59 a$ & \pm 0.02 & 4.49a & \pm 0.11 \\
\hline PRO & $4.31 \mathrm{a}$ & \pm 0.23 & $4.26 \mathrm{a}$ & \pm 0.58 & $4.45 \mathrm{ab}$ & \pm 0.09 & $4.89 b$ & \pm 0.43 & $4.61 b$ & \pm 0.02 & $4.79 b$ & \pm 0.02 \\
\hline SER & $5.61 \mathrm{a}$ & \pm 0.19 & $5.46 \mathrm{a}$ & \pm 0.08 & $5.57 \mathrm{a}$ & \pm 0.00 & $5.94 \mathrm{a}$ & \pm 0.10 & $5.48 \mathrm{a}$ & \pm 0.09 & $4.81 \mathrm{a}$ & \pm 0.01 \\
\hline THR & $5.54 a$ & \pm 0.19 & 5.43a & \pm 0.15 & 5.31a & \pm 0.04 & $5.52 \mathrm{a}$ & \pm 0.59 & 5.34a & \pm 0.11 & $4.94 a$ & \pm 0.02 \\
\hline TYR & $4.10 \mathrm{a}$ & \pm 0.38 & $4.03 \mathrm{a}$ & \pm 0.60 & $4.07 \mathrm{a}$ & \pm 0.00 & $3.88 \mathrm{a}$ & \pm 0.22 & $3.98 \mathrm{a}$ & \pm 0.16 & $3.64 a$ & \pm 0.00 \\
\hline VAL & $5.80 \mathrm{a}$ & \pm 0.47 & 5.86a & \pm 0.30 & 5.67a & \pm 0.89 & 5.59a & \pm 0.13 & 6.01a & \pm 0.20 & 6.30a & \pm 0.01 \\
\hline
\end{tabular}

Tabulated values are mean \pm SD. Values of the same line with the same letter are not significantly different $(\mathrm{p}>0.05)$. Essential amino acids are in bold. 
temperature range $\left(10-24{ }^{\circ} \mathrm{C}\right)$ observed in our study can be considered appropriate for Eurasian perch survival and growth during its early development. Dissolved oxygen concentration observed sporadically at 10 am was also generally higher than the requirement for perch survival and growth $(>7$ $\mathrm{mg} \mathrm{l}^{-1}$ ) (Fry, 1957). In literature, there is little evidence of avoidance of high $\mathrm{pH}$ up to a level 10.0. Although for many species, the preferred range was somewhat lower, varying from 5-7 to $8-9$ (Peterson et al., 1988), the punctual peak of $\mathrm{pH} 10.3$ obtained in this study at day 17 (Figure 1) did not show negative effects on growth of Eurasian perch (Figure 3).

Indeed, regular adequate fertilization maintained up to day 50 abundant zooplankton populations for perch during its zooplanktonophagous live period, ensuring a satisfactory growth rate of fish. The low number of copepods and cladocerans during this period suggested that these preys were intensively consumed by perch larvae (Figure 3 ). Several taxonomic groups of zooplankton such as rotifer, copepod nauplii, cyclopoid copepods or small soft-bodied cladocerans are potential prey items as starter live food (Craig, 1987; Guti, 1993; Wang and Eckmann, 1994). As they grow, fry progressively switch to larger cladocerans and aquatic insects (Wang, 1994; Qin et al., 1995).

Since the objective of this study was to follow body amino acid profile in Eurasian perch from larva to juvenile stages, beginning density was very high (more than 900,000 larvae $\mathrm{ha}^{-1}$ ) in able to maintain sufficient survival fish until the end of the experiment for amino acid analysis. Indeed, perch larva is known for a very high mortality at early stage in its natural environment. So, survival rate obtained in this experiment realized in a non controlled system (pond) was relatively low compared to those reported for yellow perch of comparable size reared in a fertilized pond with good management offering a more controlled system (Kayes, 1977). However, in terms of number of fry produced per unit area after 2.5 months, our results were similar to those obtained with yellow perch and walleye (Qin et al., 1995; Culver, 1996). Generally, survival rate is affected by high stocking density, probably because of a rapid emergence of cannibalism.
Specific growth rate of Eurasian perch reared in fertilized pond was very high during the first weeks after stocking $\left(38 \%\right.$ day $^{-1}$ from d1 to d7), compared to what was observed by Awaïss et al. (1992) and Fiogbé (1996) with fish fed rotifers or Artemia nauplii in intensive conditions (19.3\% day ${ }^{-1}$ and $12.5 \%$ day $^{-1}$, respectively). This suggests that rearing conditions in pond were optimal for Eurasian perch growth.

One major issue of this study is the fact that the amino acid profile remained relatively stable from newly-hatched larvae $(0.8 \mathrm{mg})$ up to 75-day old juveniles $(2.07 \mathrm{~g})$. Similar results were reported during early ontogeny of yellow perch Perca flavescens (from 0.4 to 82 mg; Dabrowski et al., 1993), but also for larger fish, such as Channel catfish Ictalurus punctatus (30-863 g; Wilson and Poe, 1985) and white sturgeon Acipenser transmontanus (20-535 g; Ng and Hung, 1994). This stable amino acid composition at different stages of perch development was probably due to the combination of various live foods, generally well balanced in amino acids compared to artificial dry diets. In natural environment, the deficiency of some amino acids in a given live prey can be counterbalanced by the excess of the same amino acids in other live organisms. Nutritionally, only the essential amino acids are required from exogenous sources (Marshall, 1994). The others can be synthesized in vivo. Inadequate levels of essential amino acids result in depression of food intake and growth.

\section{ACKNOWLEDGEMENTS}

We wish to thank A. Seabran from Millipore office for his technical assistance in amino acid analysis. This research was supported by the Ministry of Walloon Region (General Directorate of Natural Resources and Environment) and the Belgian Administration for Development Cooperation

\section{REFERENCES}

Arai S, Ogata H. 1993. Quantitative amino acid requirements of fingerling coho salmon. In Proceedings of the 10th U.S. Japan Symposium on Aquaculture Nutrition, Collie MR, McVey JP (ed). UJNR, Department of Commerce: Newport, OR, USA; $19-28$. 
Awaïss A, Kestemont P, Micha JC. 1992. Nutritional suitability of the rotifer Brachionus calyciflorus Pallas for rearing freshwater fish larvae. J. Appl. Ichthyol., 8: 263 - 270 .

Borlongan IG, Colosso RM. 1993. Requirements of juvenile milkfish (Chanos chanos Forsskal) for essential amino acids. J. Nutr. 123: $125-132$.

Craig JF. 1987. The Biology of the Perch and Related Fish. Timber Press; p.333.

Culver DA. 1996. Fertilization procedures for pond culture of Walleye and Saugeye. In Walleye culture manual, Summerleft RC (ed). NCRAC Culture Series 101, North Central Regional aquaculture Center Publications Office, Iowa State University: Ames; 115 - 122.

Dabrowski K, Culver DA, Brooks CL, Voss AC, Binkowski FP, Yeo SE, Balogun AM. 1993. Biochemical aspects of the early life history of yellow perch (Perca flavescens). In Fish Nutrition in Practice, Kaushik SJ, Luquet P (eds). Biarritz, France, June 24-27, 1991, Les Colloques, 61, Ed. INRA: Paris; 531-539.

Dagnelie R. 1975. Théorie et Méthodes Statistiques (vol. 2). Presses Agronomiques de Gembloux: Belgium; 463.

Fiogbé ED. 1996. Contribution à l'étude des besoins nutritionnels chez les larves et juvéniles de la perche fluviatile (Perca fluviatilis L.). PhD thesis, Presses Universitaires de Namur, Namur, Belgium, p. 334.

Fry FEJ. 1957. Aquatic respiration of fish. In The Physiology of Fishes, Brown ME (ed). Academic Press: London; 1-63.

Golterman HL, Clymo R. 1969. Methods of Chemical Analysis of Freshwaters. IBP Handbook, 8, Blackwell Sc. Publ.: Oxford; 166.

Guma'a SA. 1978. The food and feeding habits of young perch, Perca fluviatilis, in Windermere. Freshwater Biol., 8: 177187.

Guti G. 1993. Mortality, growth and diet of perch Perca fluviatilis L. in the Cikola branch system of the Szigetk area, River Danube. Arch. Hydrobiol., 128(3): $317-$ 327.

Hagen SR, Frost B., Augustine J. 1989. Procolumn phenylisothiocyanate derivatization and liquid chromatography of amino acids in food. J. Assoc. Off. Anal. Chem., 72: 912-9.

HMSO. 1981. Ammonia in waters. In Methods for the Examination of Waters and Associated Materials. Standing Committee of Analysts, D.O.E.: London; 46.

Kayes T. 1977. Reproductive Biology and artificial propagation method for adult perch. In Perch Fingerling Production for Aquaculture. Soderberg RW. (ed). University of Wisconsin Sea Grant College Program. Advisory report 421: 623.

Kestemont K, Mélard C, Fiogbé E, Vlavonou R, Masson G. 1996. Nutritional and animal husbandry aspects of rearing early life stages of Eurasian perch Perca fluviatilis. J. Appl. Ichthyol., 12: 157-166.

Marshall WE. 1994. Amino acids, peptides, and proteins. In Amino Acids in Farm Animal Nutrition, D'Mello JPF (ed). The Scottish Agricultural College: Edinburgh, UK; 99-112.

Ng WK, Hung SSO. 1994. Amino acid composition of whole body, egg and selected tissues of white sturgeon (Acipenser transmontanus). Aquaculture, 126: 329-339.

Ng WK, Hung SSO. 1995. Estimation the ideal dietary indispensable amino acid pattern for growth of white sturgeon, Acipenser transmontanus (Richardson). Aquaculture Nutrition, 1: 85-94.

Pechar TT. 1987. Use of acetone : methanol mixture for extraction and spectrophotometric determination of chlorophyll a in phytoplankton. Algological Studies, 46: 99-117.

Peterson RH, Coombs KJ, Pain U. 1988. Responses of several fish species to $\mathrm{pH}$ gradients. Can. J. Zool., 67: 1566-1572.

Qin J, Culver DA. 1992. The survival and growth of larval walleye, Stizostedion vitreum, and trophic dynamics in fertilized ponds. Aquaculture, 108: 257276.

Qin J, Madon SP, Culver DA. 1995. Effect of larval walleye (Stizostedion vitreum) and fertilization on the plankton community: implications for larval fish culture. Aquaculture, 130: 51-65.

Ravi J, Devaraj KV. 1991. Quantitative essential amino acid requirements for 
growth of catla, Catla catla (Hamilton). Aquaculture, 96: 281-291.

Schwarz FJ, Kirchgessner M. 1988. Amino acid composition of carp (Cyprinus carpio L.) with varying protein and energy supplies. Aquaculture, 72: 307317.

Wang N. 1994. Food and feeding of young perch (Perca fluviatilis L.) in Lake Constance. Vehr. Int. Ver. Limnol., 25: $2148-2152$.
Wang N, Eckmann R. 1994. Effects of temperature and food density on egg development, larval survival and growth of perch (Perca fluviatilis L.). Aquaculture, 122: 323-333.

Wilson RP, Poe WE. 1985. Relationship of whole body and egg essential amino acid patterns to amino acid requirements patterns in channel catfish (Ictalurus punctatus). Comp. Biochem. Physiol., 80B: $385-388$. 